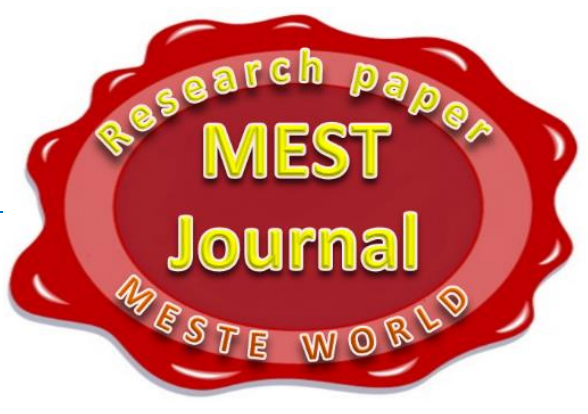

\title{
DEVELOPMENT OF THE
} ORGANIZATIONAL FINANCING MECHANISM OF INVESTMENT PROJECTS

\author{
Ekaterina Brezhneva \\ Maikop State Technological University, Maikop, Russia \\ (C) MESTE NGO \\ JEL Category: D23, D92, G31
}

\begin{abstract}
This article contains the analysis of one of the most burning issues of economic development of Russia - formation of the innovative sphere. On its basis experience of the state economic policy directed on creating favorable conditions for attraction of investments is considered. In this regard by reasoning and research of innovative system of the Russian Federation the main signs, the principles and indicators of innovative economy are allocated, existing problems in this sphere are revealed, Besides, need of participation of insurance as economic category in development of innovations for the purpose of minimization of economic risks is confirmed, the mechanism of introduction of insurance of risks in system of financing of innovative projects is shown.

Article also raises the questions of need of development of essentially new innovative security as attempt to develop the investment sphere in innovative projects for attraction of additional financial sources. Stages and the mechanism of functioning of the developed security are for this purpose designated, the characteristic features distinguishing this security from others are defined. In article the attention to need of creation of a platform for implementation of innovative projects with already allocated basic functional elements is focused.

The general result of article are offers on realization of the developed methodology on functioning of an innovative security that, in turn, will give the chance to businessmen innovators to attract investments for implementation of the projects, and investors will gain additional income with minimization of risks by means of insurance that, as a result, will allow to increase competitiveness of economy of the Russian Federation in the world market in the conditions of world globalization.
\end{abstract}

Keywords: Innovations, innovative projects, investments, the insurance of investment risks

\section{INTRODUCTION}

Currently, in The Russian Federation, the effective functioning of the innovation system is one of the

Address of the author:

Ekaterina Brezhneva

跮: Katya_Brewneva@inbox.ru most important issues for the entire national economy, because the competitiveness of domestic products depends on the performance of this field. Attracting of investment and innovative resources has a direct impact on employment of the population, creates the necessary conditions for dignified life.

Moreover, as the analysis of Russian innovation 
processes shows, innovation financing mechanism works unsatisfactorily. This is confirmed by the statistical data: in developed countries $70-75 \%$ of investments in innovation is in the private sector equity, commercial banks give a credit on $25-30 \%$ of expenditures on R\&D, and in Russia the same figures are $40 \%$ and 5-7\% correspondently.

I would like to note that one of the factors for the implementation of effective innovation is the development of serving market infrastructure. Without minimizing the importance of other factors, we note that domestic business realities dictate the rules for building a sustainable and effective innovation infrastructure.

We should note that in the Russian Federation the investment sphere at the enterprise level is presented as fragmented and underdeveloped market of investment resources, which works inconsistently and ineffectively. Poor development of market information infrastructure of the market prevents the interaction of domestic producers and potential investors. That's why it is necessary to include a new player in the investment arena insurance companies. Enhancing of the role of insurance companies in investment insurance seems relevant, that will result in:

1. creation of insurance pools and cooperation (including international insurance companies) to rank the insurance risks of major investment projects;

2. significant expansion of the boundaries of reinsurance. (Prigoda, 2011)

However, at the present stage of development of insurance products investment insurance has not received adequate attention from the Russian insurance companies yet. For developed countries the active participation of insurance companies in the investment process is typical, where they act as investors, providing a third of all investments in their countries. In the West insurance covers $90-95 \%$ of all possible risks, while in Russia it is below 7\%. Among the main causes of this are:

1. lack of state financial support for Russian insurers;

2. lack of internal resources to take responsibility for major risks;
3. underdeveloped infrastructure, which would guarantee the proper pre-insurance expertise of investment claims;

4. inexperience and lack of qualified personnel.

According to some researchers as Toffler (1992), Fukuyama (2014), Bell (1980), Naisbitt (2010), and others, most of the developed countries in the world, with innovation-oriented economy, have their global economic supremacy just due to the implementation of successful policies in the field of innovations. Analyzing it, we can conclude that many scientists have similar opinion in identifying and naming principles, signs and indicators of the innovation economy (Figure 1).

\section{DISCUSSION}

The innovative economy has its own tools, system of tasks and priorities. At the same time, a feature of the national innovative economy in Russia is that the "end" objectives is virtually impossible to achieve without the organization of a favorable investment climate, a guarantee of quality implementation of basic economic rules, a competitive environment for creating marketbased incentives to innovations and solving a number of other key problems in the sphere of institutional infrastructure building. Among the most profitable and stable I single out investments in securities with fixed interest. In Russia, bank deposits dominated until recently, but with a decrease in bank interest priorities have shifted to government securities. The solution to the problem of investment activity in Russia, in our opinion, will become the investments in securities of enterprises.

Investment risk is associated with the specific of business company investments in various projects. Actually financial investments are transactions in order to obtain speculative income. The investor usually has risks of these transactions, and practically the only protection against them is the reputation and the guarantee of the borrower or issuer of the securities specified in terms of production or loan agreement. Insurance of such risks increases in demand in the market. 


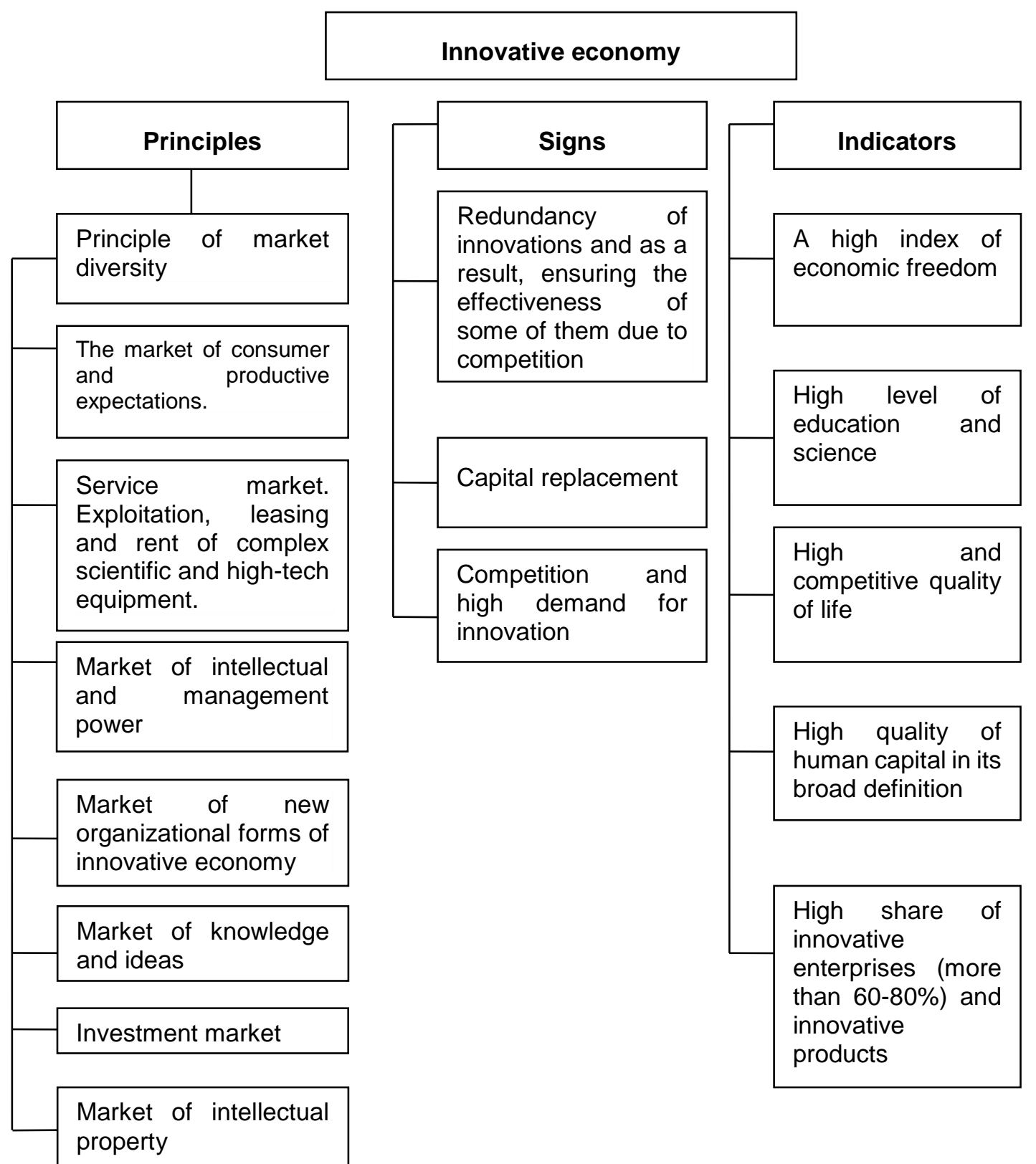

Fig. 1. Basic principles, signs and indicators of innovative economy

(Source: Author)

In modern conditions, part of the financial market is the securities market, which provides the fastest spillover of financial resources to investments. It allows companies to raise significant amounts of money on any time and usually on more favorable terms than a bank loan. In this regard, task solution for development and implementation of a mechanism for raising investments in innovative business characterized by its novelty seems appropriate. This mechanism is based on the issue of securities, which allows intensifying investment activity of big players and small players, including individuals. The stages of development process, issue and placement of securities are shown in Fig. 2. 


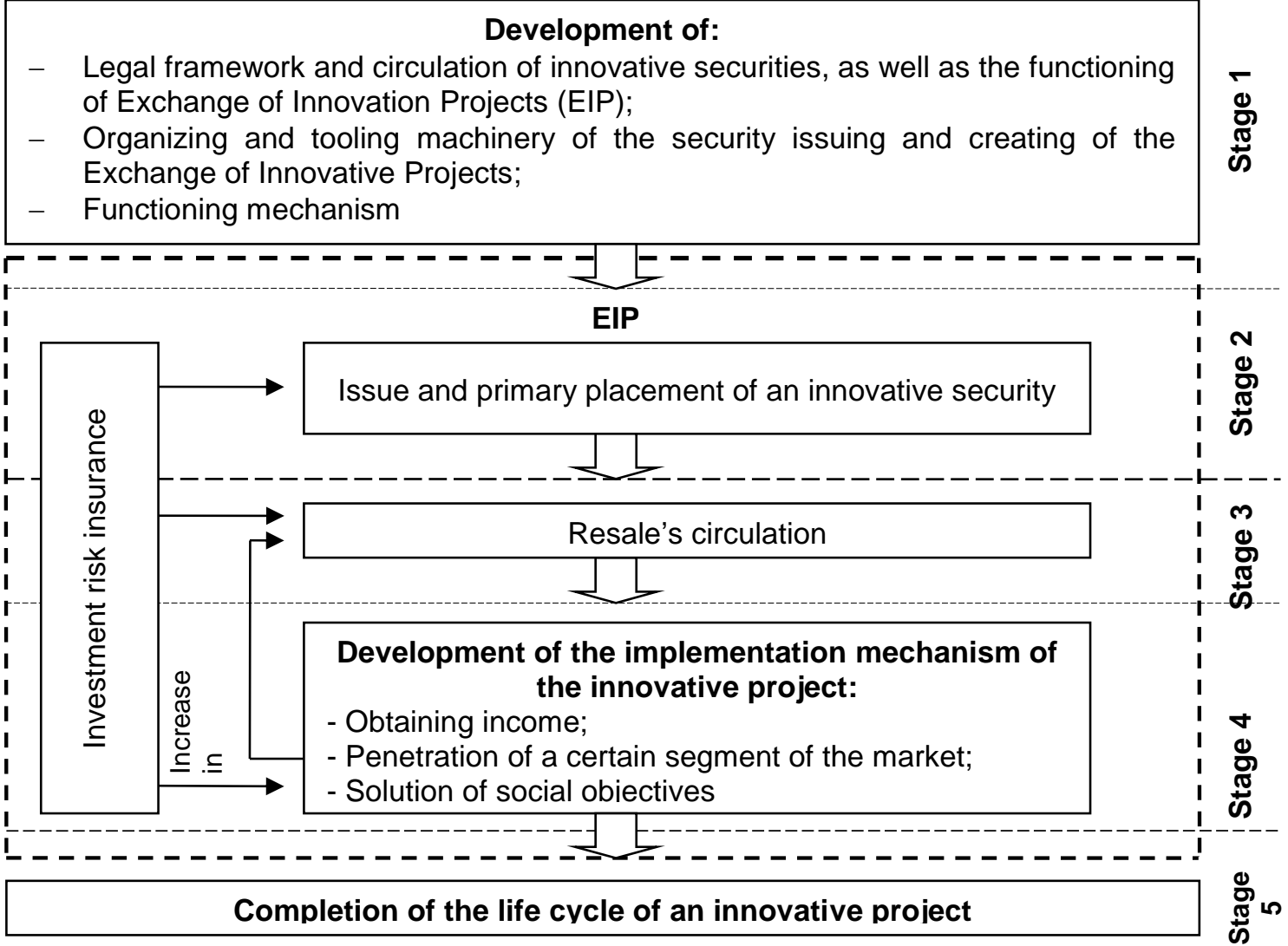

Fig. 2. Stages of the development process of development, issues and a the placement of an innovative security (Source: Author)

We will discuss each stage in details.

\subsection{Stage 1}

For the purpose of fund raising a companyinnovator is asked to produce issue of innovative securities, which give the investors the opportunity to share in the project, developed by the issuing company. In practice, this kind of security paper does not exist. In this regard, we consider that it is necessary to make the development of the mechanism of emission and circulation of innovative security Single.

Single is a security that reaffirm the share participation of its owner (investor) in the company-innovator (the issuer) project, who has issued a given security. When the project will generate income, the issuer agrees to pay the interest, which will depend on the demand for the product. The Single will have characteristic features that distinguish it from other types of securities:

- the ratio of investor share participation in the project. Person who has acquired Single, is not a co-owner of innovative company but becomes a co-owner of the project developed by this company;

- circulation period. The Single expiration date is equal to product life cycle, based on the innovative project;

- yield of a security. The size of interest payments on Single will be directly proportional to the demand for innovative product made within the project;

- liquidation procedure. In case of project liquidation Single holders are not compensated for investment expenses.

The company resorts to the Single issue to attract additional investments. 


\subsection{Stage 2}

Project life cycle begins with the issue - the process of single documenting and putting into circulation. As a result of the issue and placement in the primary market innovative security finds its owner (individual or legal entity). After the Single is sold in the primary market, it goes to the new owner and thus completes its first cycle of circulation.

Moreover, investment risk insurance on securities is implemented at this stage. This element extends through all remaining stages of "life" of the security, as any work with something new involves a certain degree of risk and can lead to financial losses. To avoid this, we invite the investors to protect themselves by compulsory risk insurance. (Federal law, 2015) It should be noted that insurance coverage for investment insurance in the Single will be based on one of the following objects of insurance:

- annual income of the investor;

- $\quad$ the difference between the dividend amount and actually received dividend payout;

- $\quad$ revenue for the entire period of project "life" by Single;

- the risk of losing the capital invested in the purchase of Single.

The main task of the primary market is to ensure a flow of financial resources for issuers. When issued Single start further movement in the securities market, they appear on the secondary market.

\subsection{Stage 3}

Single placement on the secondary market. Since Single is a security specially created to reflect the share participation of the investor in the companyinnovator projects and acts as a special tool, hence the organizational structure of the secondary market on which innovative companies will focus, should be specially designed.

We propose to develop a qualitatively new platform for the implementation of innovative ideas - Exchange of Innovation Projects (EIP) to accommodate Single, thus the project will find its investors.

The main objective of the creation of EIP is joining of companies- innovators, which wish to obtain financing for the development of their innovative projects by placing Single and investors who have temporarily free resources and are willing to invest in Single of effective and innovative projects. EIP would "put out" inefficient projects by special methods of examination conducted by its structural element, that will protect investors from undue risk of losing their investments.

The main parts, the main functional elements of the EIP are presented on Fig. 3.

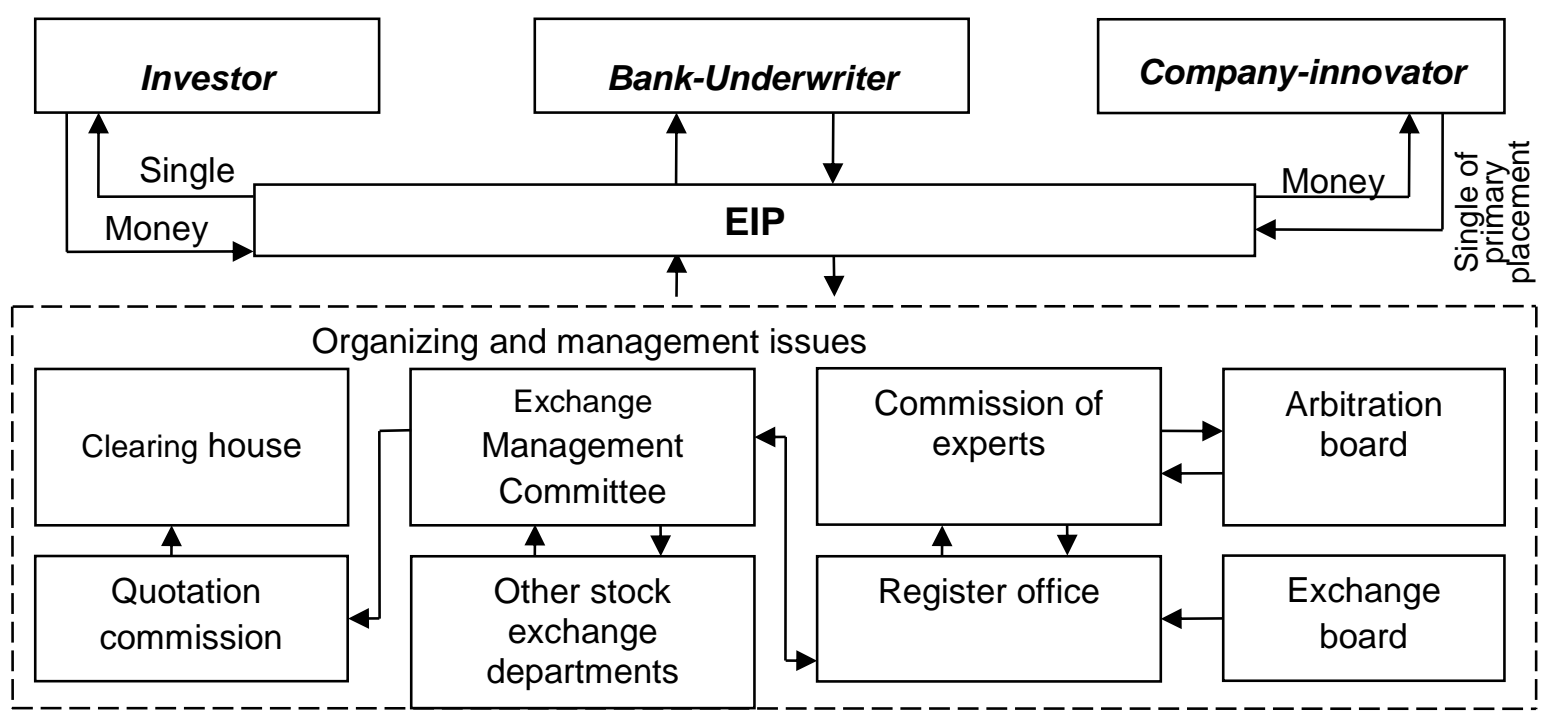

Fig. 3 EIP functioning model (Source: Author)

Investors of innovative projects can be:

- legal entities;
- individual entrepreneurs;

- commercial banks. 
Everything is clear with legal entities and individual entrepreneurs, but the place of a commercial bank within EIP is ambiguous, since the bank can perform two functions:

- act as investor by acquiring Single projects, which are already posted within EIP;

- act as underwriter.

Let us dwell on the second option, since it is the topping. Bank as underwriter is a professional member of EIP and performs the following functions:

- consideration of the application and business plan;

- carrying out input, scientific, technical and investment expert examination, reference of a project to the regulatory body of EIP;

- listing procedure;

- Single issue on behalf of the companyinnovator;

- $\quad$ preparation of issuing documents;

- preparation of memorandum;

- marketing and preparation for placement on EIP;

- placing on innovative platform.

Valuation of the company is based on the process and generalization of the following information:

- risk is determined on the basis of the significance of the economic sector;

- market condition;

- $\quad$ production efficiency - the ratio of costs and benefits;
- management - results of financial transactions;

- accounting - general evaluation of the use of accounting methods and reflection completeness of the financial condition;

- profitability - basic measurements characterizing the company's efficiency in the long term;

- financial solvency - the ratio of total debt to equity capital, and etc.

Acting as underwriter, bank-investor adopts a role of mediator, guaranteeing a certain amount of Single redemption for himself and public offering of the rest part on EIP.

Thus, the company-innovator immediately receives a share of investment from the bank, and then the remaining amount on the placed Single from foreign investors, attracted by the bankunderwriter.

If the company-innovator decides to repurchase issued Single due to the improved financial position and ability to independently conduct its business or other reasons, the investor has the right to sell Single at a price fixed at the date of sale. The difference between the purchase price and the selling price will be the investor's gain (expense).

The advantages of bank-underwriter participation in company-innovator project investment are presented in Table 1.

Table 1 The advantages of bank-underwriter participation in investment process (Source: Author)

\begin{tabular}{|l|l|}
\hline \multicolumn{1}{|c|}{ For company-innovator } & \multicolumn{1}{|c|}{ For bank-underwriter } \\
\hline $\begin{array}{l}\text { Qualitative assessment of the financial } \\
\text { condition due to the bank-underwriter analysis }\end{array}$ & $\begin{array}{l}\text { Opportunity to select the most promising } \\
\text { developments }\end{array}$ \\
\hline Accelerated and simplified procedure of listing & $\begin{array}{l}\text { Commission remunerations for underwriter } \\
\text { services }\end{array}$ \\
\hline $\begin{array}{l}\text { Time saving for preparation of relevant } \\
\text { documentation for Single issue }\end{array}$ & $\begin{array}{l}\text { Risk ranking by simultaneous investment in } \\
\text { multiple projects }\end{array}$ \\
\hline $\begin{array}{l}\text { Issue of Single by bank on behalf of the } \\
\text { innovator }\end{array}$ & Revenue from project implementation, margin \\
\hline Single placement by bank on EIP & Rating change towards quality improvement \\
\hline $\begin{array}{l}\text { Acquiring of part of the investment from the } \\
\text { bank within the specified period }\end{array}$ & Increase in the customer base \\
\hline $\begin{array}{l}\text { Settlement, cash, exchange and other services } \\
\text { at special rates }\end{array}$ & $\begin{array}{l}\text { Income from providing settlement, cash, } \\
\text { exchange and other transactions }\end{array}$ \\
\hline
\end{tabular}


Underwriters act as intermediaries between the end investor and company- innovator connecting their interests and at the same time as the authorized representatives acting on the stock exchange as trustees of owners of implemented innovative product and its buyers.

Thus, the underwriter carries out its activity for and on behalf of the client, their relationships are based on a contractual basis. Underwriter's income is formed by the commission fees of the sum of transaction.

\subsection{Stage 4}

This stage includes a development of a mechanism for the implementation of an innovative project that describes the system of income generation, strategy to gain a particular market segment and aimed at solving social problems.

Income by Single consists of:

- income in the form of interest accrued and paid on a monthly basis from the date of the project recognition on the market;

- income in the form of discount, which is a positive difference between the purchase price and the redemption price of investment security.

Procedure for interest payment by Single is:

- the source of income payment by Single is net profit;

- in case of absence of net profit, the interest payment shall be suspended until it becomes available;

- if there is no interest payment (systematic), it can serve as a recognition of inefficiency of the project. As a result, the project may be suspended or removed from sale.

Investments in specific projects by security Single can be protected by insurance. Typically, this type of insurance is expensive because it requires a complex and expensive pre-insurance expertise, which in turn greatly reduces the investment return. Therefore, Russian insurers are just beginning to insure investment risks. We do offer to make risk insurance associated with the implementation of investment project mandatory.

Innovative risk insurance must be considered as a special kind of insurance. This insurance includes all types of risks that arise during the creation, development and embedding of innovative activity objects. Therefore, special attention is paid to the interaction between the insurer, companyinnovator and reinsurance company.

\subsection{Stage 5}

The completion of the life cycle of an innovation project. After a certain period of time projects tend to end (each project has its period), when all objectives are achieved. There are cases when the end of the project is sudden and premature, including cases when the decision to stop the project until its completion on schedule is made. The final stage of the project life cycle is its obsolescence, a significant decrease in the practical application. At the final stage, as a rule, the project is replaced by more improved one.

The application of the developed tools for ensuring sustainable development of the company on basis of formation and use of monitoring system of innovative capacity in practice let to reasonably review the strategic guidelines of innovative enterprise activity on innovation and gain economic benefits, expressed in the sustainable development of the enterprise, strengthening its position in the market, increasing the efficiency of its operation.

\section{CONCLUSIONS}

Based on the foregoing, we can draw the following conclusions.

Russia failed to bring science and private sector to one level. And today it is a fundamental task for Russian politicians. Investing in investments is one of the most advanced areas to ensure the development of broad innovative activity in the country.

It is necessary to create a special innovation infrastructure for the innovative economy development and stimulation of the process of new markets formation. On the territory of the Russian Federation innovations are created, often surpassing their Western analogues, both in quality and in low price. The problem is that in reality the system of scientific and technical analysis and search is not completed. In order to solve this problem, as a result of our work the 
mechanism for attracting investments in innovative sphere was developed, namely:

- innovative security Single, that gives the opportunity for investors to share in the project developed by the issuing company is developed;

- issuing mechanism and innovative security circulation is thought over;

- organizational structure of a qualitatively new platform for the implementation of innovative ideas - Exchange of innovative projects (EIP) to place innovative security (Single) is developed;

- mechanism for the implementation of innovative project is designed:

- income generation;

- occupation of a certain segment of the market;

- the solution of social problems.
Despite all the problems that accompany the introduction of innovative risk insurance in the Russian practice, it appears that the demands for insurance in The Russian Federation are objective, and sooner or later there will appear the interlayer of reasonable entrepreneurs who will be able to properly assess their risks and opportunities, realize the profitability of development of innovative risk insurance, and this type of insurance will get a decent practical implementation.

In our opinion, the implementation of the proposed methodology will enable entrepreneurs-innovators to attract investments for their projects, and investors will receive additional income with risk minimization through insurance, which, in turn, will improve the competitiveness of The Russian Federation in the global market.

\section{WORKS CITED}

Bell, D. (1980). The Social Framework of the Information Society. In J. Forester, The Microelectronics Revolution (pp. 500-49). Oxford: B.Blackwell.

Federal law. (2015, Apr 06). Federal Law of the Russian Federation from April 22, 1996 of No. 39-FZ About the security market. Retrieved from CIS-Legislation: http://cislegislation.com/document.fwx?rgn=1782

Fukuyama, F. (2014). Political Order and Political Decay: From the Industrial Revolution to the Globalization of Democracy. Farrar, Straus and Giroux.

Naisbitt, J. (2010). China's Megatrends: The 8 Pillars of a New Society. New York: HarperBusiness.

Prigoda, L. (2011). Modernization and innovations in the Russian economy: long-term strategy of development. Materials of the International scientific and practical conference "Economic and legal aspects of the modernization strategy in Russia: mechanisms ensuring competitiveness and high-quality economic growth", (p. 56).

Toffler, A. (1992). Powershift. New York: Bantam Books.

Received for publication: $\quad 31.03 .2014$

Revision received: $\quad 05.04 .2015$

Accepted for publication: $\quad 11.05 .2015$

\section{How to cite this article?}

Style - APA Sixth Edition:

Brezhneva, E. (2015, July 15). Development of the organizational financing mechanism of investment projects. (Z. Čekerevac, Ed.) MEST Journal, 3(2), 1-9. doi:10.12709/mest.03.03.02.01 
Style - Chicago Sixteenth Edition:

Brezhneva, Ekaterina. 2015. "Development of the organizational financing mechanism of investment projects." Edited by Zoran Čekerevac. MEST Journal (MESTE) 3 (2): 1-9. doi:10.12709/mest.03.03.02.01.

Style - GOST Name Sort:

Brezhneva Ekaterina Development of the organizational financing mechanism of investment projects [Journal] // MEST Journal / ed. Čekerevac Zoran. - Belgrade : MESTE, July 15, 2015. - 2 : Vol. 3. - pp. $1-9$.

Style - Harvard Anglia:

Brezhneva, E., 2015. Development of the organizational financing mechanism of investment projects. MEST Journal, 15 July, 3(2), pp. 1-9.

Style - ISO 690 Numerical Reference:

Development of the organizational financing mechanism of investment projects. Brezhneva, Ekaterina. [ed.] Zoran Čekerevac. 2, Belgrade : MESTE, July 15, 2015, MEST Journal, Vol. 3, pp. 1-9. 